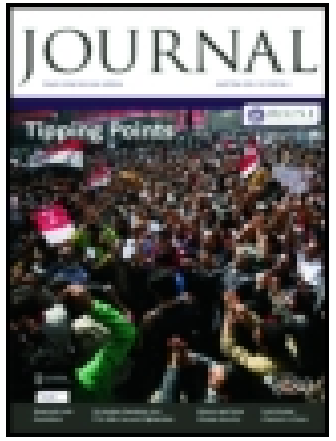

Royal United Services Institution. Journal

\title{
On the Geneva Convention of August the 22nd 1864, with Some Account of the National Committees Formed for Aiding in Ameliorating the Condition of the Sick and Wounded of Armies in Time of War
}

\section{Deputy Inspector-General T. Longmore}

To cite this article: Deputy Inspector-General T. Longmore (1866) On the Geneva Convention of August the 22nd 1864, with Some Account of the National Committees Formed for Aiding in Ameliorating the Condition of the Sick and Wounded of Armies in Time of War, Royal United Services Institution. Journal, 10:39, 162-182, DOI: 10.1080/03071846609427021

To link to this article: http://dx.doi.org/10.1080/03071846609427021

\section{曲 Published online: 11 Sep 2009.}

\section{Submit your article to this journal $\longleftarrow$}

Џll Article views: 2 


\section{LECTURE.}

Friday, Mrarch 16th, 1866.

MIsor Sir IIIRRY VERNEY, Bart., M.P., in the Chair.

ON TIIE GENEVA CONVENTION OF AUGUST TITE 22ND, 1864, WITH SOME ACCOUNT OF THE NATIONAL, COMMIITTEES FORMIED FOR AIDING IN AMELIORA'INTG TIIE CONDITION OF THE SICK AND TOUNDED OF ARMIES IN TIME OF WAR.

By Deputy Inspector-General T. Loxgyone, Professor of Military Surgery at the Army Medical School.

The Crmamax : I have the pleasure of introducing to you Professor Longmore, Professor of Military Surgery at the Royal Victoria Ilospital, Netley. He has seen a great deal of service in the Crimea, and he has given particular attention to the subject which he brings beforo us to-day. l'rofessor' Longmore was sent by our Gorernment to the Conference which was held at Geneva two years ago; and I beg to mention to you that this morning Miss Nightingale said to me, she thought there was no person better qualified to give an opinion upon the subject, aud to discuss it, than Professor Longmore.

Professor Loxgxone : In the carly part of last winter it was intimated to me that the Council of the Royal United Service Institution desired to hare a lecture on the subject of the International Congress, which was held at Geneva, in 1864, for ameliorating the condition of the wounded soldiers of armies in the field by obtaining a treaty for their nontralization, and I was asked if I would undertake its delivery. I acceded to the request without hesitation, and I did so for two reasons. 'The first was that I knew there existed no little misapprehension in the minds of some persons in this country respecting the objects of this Congress, and considerable doubt as to the practicalility of carrying into effuct the terms of the international treaty which resulted from it; the second was, that having had the honour of being sent to the Congress as one of the representatives of the British Goverument, and, moreorer, having acted at the Congress as one of the members of the sub-committee, whose duty it was to wreigh carefully the written terms in 
which ench article of the Convention was expressed, I felt I probably possessed the means of removing some of the misapprehensions to which I have referred, and of showing that the treaty contains nothing which is impracticable or inconsistent with national or military requirements. It also appeared to me that I might, perhaps, be of use by calling attention to the advisability of steps being taken in this country for the formation of a national committee, similar to the committees which have becn formed in most other European countries, for aiding their respective Governments in time of war in ministering to the necessities of sick and wounded soldiers. I an impressed with the importance of the subject being considered now, while we enjoy the leistre of peace ; and of the committee, if one should be formed in this country, being organised and directed by persons holding positions of social weight and influence, as well as by officers possessing extended military experience; so that whatever preparations may be made, or coursc of action resolved upon, the steps taken in case of war brealing: out may be uniform, may be such as will excite sympathy and confidence in the nation at large, and, at the same time, such as will harmonize with the necessities of campaigning and the general arrangements of military service. Keeping the sereral objects I have named in view, I propose, 1stly, to lay before you a brief slietch of the circumstances which gave rise to the International Congress in 1864 ; 2ndly, to explain the results of the Congress, as exhibited in the articles of the Convention acceded to by IIer Majesty's Government; and, 3rdly, to describe the functions of the National Committecs which have been formed in tho principal countries of Europe, as well as to submit a few reasons for the establishment of a similar committeo, in this country.

Firstly, then, as to the history of the Congress. No one who studied the moral and political progress of a nation can fail to notice the prominence of certain successire periods in its history, within each of which a gencral condition has been arrived at, notably favourable for the development of some fresh and important adrance in cirilisation which has followed. It seems to be similar in moral progress to what we often obscrve in the progress of physical science, which, owing to successive additions to its stores of knowledge, and to concurrent circumstances, from time to time reaches such a stage of improrement, that important discoveries, or valuable applications of the information alrendy gained, spring from it, - almost spontaneously, as it were, and occur to the minds of several individuals nearly at one and the same moment. The npostles of moral and political advancement, whose names are household words among us, have, in frequent instances, owed their success and influence, not merely to their own zealous efforts, but also to the fact that they raised their voices at a time when many had become prepared and well disposed to listen; whereas others, equally z.calous, and of equal porrer, had previously failed in adrocating the same doctrines, because the period favourable for their reception had not yet arrived.

So it seems to hare been in respect to the International Congress and treaty of which we are now speaking. There was nothing in the 
objects of the Congress, there is no provision in the treaty, which has resulted from it, which had not been previously adrocated by able and earnest men of various countries. Not only had individuals adrocated, but in some instances the commanders of armies in the field had of their own accord agreed to and carried into effect, the principles embodied in the articles of the Geneva Convention. Such instances, howerer, hare been few, and are remarkable as exceptional cases. The fitting time has only recently arrived for what was exceptional to become the rule, for such topies as those which are embraced in the Geneva Conrention to excite general interest, and to be held to be of sufficient importance to European Governments to enter into a treaty respecting them. We must look to the rast increase in the means of diffusing information; to the facilities for rapid personal intercommunication; to the general attention now paid to the great events which stir mankind, of which wars are among the most stirring in their nature and their consequences; to the spread of more civilised and humane feelings, and the abatement of national animosities; and to the higher estimate of the value of life everywhere, if we seek for an explanation of the altered circumstances of our times in respect to the matters of which I am speaking.

The moral infuences, no less than the military circumstances of modern battles are greatly changed by the changed conditions of things around us. While the names of the killed are hardly known at the place of action itself, while the numbers of the wounded are scarcely counted, electric messages inform the world that a battle has been fought, that a victory has been achieved, or a reverse sustained. The fears and hopes of thousands are at once excited, and general sympathy is awakened. Thile the wounds of the wounded are still recent, and the lives of many who are under the care of the military surgeons are still trembling in the balance, private communications from comrades, or from friends who hare hastened to assist in the relief of sufferers, and public accounts multiplied and diffused far and wide by the press, rouse the attention of all ranks of society to individual concerns, and to detailed incidents of the conflict, to an extent which was unknown, and, indeed, impossible before the existence of telegraph wires, railroads, steam, and of all the machinery for the rapid diffusion of intelligence and personal observations, which exist in our epoch. In former days the general results of war were made public, the knowledge of personal circumstances was exceptional and limited to a narrow'sphere; now the personal are almost as widely known as the general results. No wonder, then, on the one hand, that in former days the evils of war, being regarded as incapable of mitigation, or being unknown until all power of affording aid was passed, were left to be dealt with entirely by the governing authorities; or, on the other hand, that in our time public sympathy has sought to lessen these evils by committees of relief, by volunteer assistance, by donations of materials, by patriotic associations for the support of widows and orphans, by the special employment of soldiers disabled for ordinary occupations, and by various other means too numerots to be nentioned or even that the mitigatlon of tho tigrours 
and sufferings of war shonld be thought worthy of being made an object of international concern.

It was undoubtedly to the direct infuence of the rork, written by Monsicur Henry Dunant, entitled "Un Souvenir de Solferino," as well as to the personal exertions of that gentleman, that the morement which led to the International Congress of $186 t$ and its results was immediately due. Monsieur Dunant, a Swiss gentleman, was travelling in Italy on his own account in the year 1859, and was in the neighbourhood of Solferino on the day of the great battle of the 24th of June. The aspect of the battle-field, the sufferings of the vast numbers of wounded scattered over it, and the occurrences which he afterwards witnessed in tho hospitals, where M-Lonsieur Dunant remained for some days assisting as a volunteer in attending upon the wounded, excited in him the strongest mental emotions. Notwithstanding the able arrangements of Baron Larrey, the chief of the medical servico in the field; notwithstanding the liberal provision which had been made by the administrative functionaries of the Freuch army; in surgeons, in the means of transport, surgical stores, and sick dietary; notwithstanding, in addition, the aid afforded by some of the inhabitants of the places to which tho wounded were first brought, M. Dunant saw that many of the wounded, owing to the rastness of their number, were left for some days without attention, and still longer without an adequate amount of nursing and surgical relief, and lie was led to consider whether there were any means by which this superadded suffering in time of war might bo obviated. Thus was formed the train of ideas which subsequently led to tho publication of the "Souvenir de Solferino" in 1862.

The work may be regarded as consisting of two parts, although tho diction is continuous; the first being a description of the incidents which MIonsiour Dunant had observed in the battle-field and in the improvised hospitals at Castiglione, on the road to Brescia, and elsewhere; the second being a series of arguments in favour of a proposition for founding in every country permanent socictics of persons willing to prepare themselves for supplementing the regular military establisliments of surgical assistance in time of war- roluntecrs trained and organized beforehand for carrying the wounded from the field, and for attending upon them afterwards in hospitals with requisito skill and care, under the direction of competent authority. Since it was on the ficld of battle, and in the crowded temporary loospitals in its immediate neighbourhood, that Monsieur Dunant had chiefly observed the want of sufficient assistance, it was in these situations that M. Dunant thought aid could most efficiently be given by devoted volunfecrs acting from motires of humanity and patriotism. I will notice presently how far such a system appears practicablo to those who have considered the subject.

M. Dunant's work created a great sensalion, and was quickly'translated into several European languages. At the time of its publication there existed, and still exists, at Geneva a society called the Generese Society of Public Utility (La Société Generoise d'Utilité Publique), and this society appointed a committee, of which General Dufonr, the Genes 
ral-in-chief of the Swiss Confederation, accepted the presidency, for the purpose of supporting and encouraging the dissemination of the proposals which liad cmanated from MI. Dunant. The action of this commiltce subsequently led to the convocation of an International Conference on the subject. This was held at Geneva in October 1863, and was attended by delegates from sixteen Gorernments, riz., fron dustria, Baden, Bavaria, Belgium, France, Great Britain, Ilanover, HesseDarmstadt, Italy, Prussia, Russia, Saxony, Spain, Sweden, Switzerland, and Wurtemberg. This Congress, which must not be confounded with the subsequent Congress of 180t, sat foir days, and discussed sereral articles which were laid before the assembled delegates for consideration by the Generese Committee before named. Some of tho propositions contained in these articles were assentel to ; others, especially those relating to the organization of corps of roluntecr hospital nttendants inrested with independent action, were only accepted in part, and became considerably modified in the resolutions which the delegates finally agreed upon.

The delegates adopted and recommended a proposal that in erery country central and sectional committees should be formed, for the purpose of supplementing in time of war, by every constitutional and practical means in their power, the regular lospital scrvice of tho army. But they did not support the articles in mhich propositions were contained for voluntecr hospital attendants to be organized under engagements to serve during definito limited periods, with the right of being cmployed, according to their own desire, on duty in the ficld or in the hospitals. The articles proposed that these roluntecrs should wear a distinctive uniform; that their exclusively charitable charncter being recognized, their persons should be held sacred; and lastly, that following in the rear of armics, they should make no claims on the armies which they accompanied; but that they should take with them their own provision of means of transport, rations, and the material necessary for the exercise of their functions.

It was obvious enough to officers of military experience that these proposals, as they stood, would lead to interference with that unity and supremity of control which is so essential for military discipline and success, even if they were not altogether impracticable, and they finally assumed at the hands of the assembly the following shape: that the National Committees, meler whose direction the volunteer hospital attendants would bo trained, should, in concurrence with the military authorities, designate the places where they were to attend upon the wounded; that on the demand, or with the permission of the military authorities, the National Conmittees might send voluntecrs into the field on the understanding that, while there, they were. to be placed exclusively under the order of the Commander of the Forces for duty. So far, then, as regards the manuer in which the propositions which were submitted to this Conference of 1863 were dealt with; in addition, however, before separating; the delerates recorded by general vote a strong appeal to the Goremments of all civilized nations to come to an agrecment for according the benefits of nentrality to all soldiers of regular armies, whatever nation they might belong to, who 
had the misfortune to be placed hors de combat by wounds or sickness in time of war, as well as to the hospitals recciving them, the hospital staff and attendants, and to any of the inhabitants at the seat of war who might give them assistance; that a common recognizable sign should be adopted to indicate the medical staff of all armies; and that a common flan: should be adopted in erery country to designate the military hospitals.

Two actions followed the resolutions of the International Assembly of 1863. One of these was the formation of National Committecs in various countries; among others, in Austria, Prussia, and Denmark, where the committees were soon called upon to discharge their functions practically in the war which shortly afterwards occurred in Schleswig-FIolstein. The sccond was a course of proceeding which ultimately led to the International Congress of 1864, for the purpose of considering the question of the neutralization of the sick and wounded soldicrs of belligerent armies. This is the Congress from which the Conrention emanated which we shall have to consider presently.

This Congress was assembled in accordanec with a request from the Supreme Federal Coumcil of Switzerland. The Geneva Committee which I have before mentioned, and to which the designation of "International Committee" had becin given at the Conference of 1863 , liaving ascertained that fifteen of the Cabinets of Europo were favourable to the adoption of a treaty for the neutralization of sick and wounded soldiers in time of war, as well as of the personnel employed in attending upon them, solicited the Swiss Government to invite the other Gorermients to take part in a General Congress for discussing and agreeing upon terms on which a convention on the subject might bo based. The Federal Council acceded to the request, and proposed. Genera as the place of meeting, and the 8th of Angust as the time for opening the Congress. It was felt that Switzerland, with no permanent army of its own, and placed as a mation in an independent position, as it were, with regard to the conflicting interests of the great European powers, might initiate such a morement with grace and propriets.

The invitation was accepted by sixtecn powers, and the Congress was opened, on the date before named, in a portion of the IIotel de rille at Geneva, which was furnished for the occasion by the Federal Government. The representatives, trenty-fivo in number, consisted of members of the diplomatic service, as well as officers of the military and medical staff of various armies. The deliberations lasted nearly a fortnight, and the terms were finally agreed upon for the Convention which was signed on the 22nd day of $A$ ugust by the representatives of twelve Governments who had accredited their delegates with sufficient powers for signing a treaty. Subsequently it was adhered to by four others, including our own Government. The accession of the British Government to the Convention was signed at London on the 18th of February, 1865.

The Gorernments which have acceded to the Convention, in addition to the Government of England, are those of France, Prussia, Spain, Portugal, Ilolland, Belgium, Italy, Switzerland, Greece, Denmark, 
Sweden and Norway, Mecklenburgh-Schwerin, Baden, Wurtemberg, and Hesse-Darmstadt.

This is a remarkable instance of a gencral treaty brought about by the exertions of an individual in private life; at the same time, without the actiro support and operations of the International Committec of Genera, but, above all; without an adranced philanthropy inducing a strong general desire for lessening as much as practicable the evils of war to individual soldiers, who, after all, hare no personal feelings in the conflicts in which they are eugaged, who only act as instruments; without these aids, it is more than probable that the benerolent efforts of Monsieur Dunant would never have achieved the work they at last accomplished.

I hare thus rapidly glanced at the history of the circumstances which led to the International Congress of 1864 . I have now to give some account of the sureral articles of the Convention which resulted from it.

It is importantito understand that the particular aim of this Congress was to obtain tho neutralization of wounded of belligerent armies and of the personnel and materiel which aro necessary for their care and treatment. Hitherto it has not been the custom of war to regard soldiers disabled by wounds, any more than the surgeons or others in attendance upon them who might fall into the hands of an enemy, as neutrals. $\Lambda \mathrm{s}$ already noticed, in a few exceptional instances, from motives of generosity or by special agreement between hostile generals, both wounded soldiers and military surgeons haro been so regarded; but the gencral custom has beerr to regard them as prisoners of war, and, like all other prisoners, only to be given up on the principle of exchange. Equally all hospital and ambulance transport equipment or materials falling into the liands of the enemy were regarded as prize of war. The Congress of 1864 was solely to determine whether the humane principles which had now and then been applied exceptionally, might not, under certain limitations, be rendered consistent with military necessities on all occasions, and be established as a rule.

As to the question of a common flag, if tho sick and wounded were to be treated as neutrals by belligerents, and if the military hospitals, attendants, ambulance transport, and the surgical materials necessary for the wounded were to be included in the protection accorded to the wounded themselves, it would naturally follow that a common flag, or some other recognisable sign, would be necessary to indicate them, so as to secure the protection they were entitled to.

I have dwelt upon the special purpose of this Congress, because it was supposed by some persons that the question of independent volunteer attendants, which had been discussed, as I have already mentioned, in the former assembly of 1863, was again to bo opened and discussed in the Congress of 1864 . This erroneous supposition led to the Congress being regarded with suspicion, and even with positive disapprobation, by some who would doubtless have regarded it very differently had 20 stch views been entertinted by 
them. But it was only on a positire understanding that this question was not to be rc-opened, and with a pre-determined resolution not to join in any treaty which included the admission of independent volunteers, that some of the delegates were sent by their respective Governments to the Congress. On examination of the articles of the Convention it may be noticed that all allusion to volunteers has been rigorously excluded from the treaty. In case of voluntecr corps of hospital attendants being organized, there are other fields open for the exercise of their patriotic and charitable functions besides thoso with the armies operating in the field, where endless difficulties might arise from their independent presence under the ordinary circumstances of campaigning: Should their services be required in the field by the supreme military authority, they would doubtless only be accepted on the condition of the men of the corps becoming incorporated and forming for the time, part of the military establishment, and of their being subject to all the rules and articles of war; and then they would fall under the benefits of the treaty, because they would be comprised in the personnel of the hospitals under the second article.

The articles in which the terms of the Convention are cmbodied are nine in number, and the following is a copy of them in the translated form in which they were presented when the accession of the British Government to the treaty, was laid before Parliament.

"Articles of the Convention, signed at Geneva, August 22nd, 1864, for the amelioration of the condition of the Wounded in Armies in the field, and acceded to by the British Government on the 18th February, 1865.

\section{Article 1.}

"Ambulances and military hospitals shall be acknowledged to be neuter, and, as such, shall be protected and respected by belligerents so long as any sick or wounded may bo therein.

"Such neutrality shail cease if the ambulances or hospitals should bo held by a military force."

\section{Article 2.}

"Persons employed in hospitals and ambulances, comprising the staff for superintendence, medical service, administration, transport of wounded, as well as chaplains, shall participate in the benefit of neutrality whilst so employed, and so long as there remain any wounded to bring in, or to succour."

Article 3.

"The persons deaignated in the preceding article may, etet

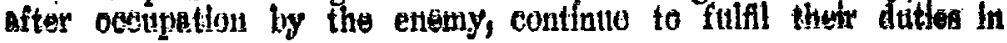


the hospital or ambulance which they serve, or may withdraw, in order to rejoin the corps to which they belong.

"Under such circumstances when those persons shall cease from their functions they shall be delivered by the occupying army to the outposts of the eneny."

\section{Article 4.}

" $\Lambda$ s the equipment of military hospitals remains subject to the law's of war, persons attached to such liospitals cannot, in withdrawing, carry away any articles but such as are their private property.

"Under the same circtunstances an ambulance shall, on the contrary, retain its equipment."

\section{Article 5.}

"Inhabitants of the country who may" bring help to the wounded shall be respected, and shall remain frec. 'The generals of the belligerent powers shall make it their care to inform the inliabitants of the appeal addressed to their humanity, and of the neutrality which will be the consequence of it.

"Any wounded man entertained and taken care of in a house shall be considered as a protection thereto. Any inhabitant who slall lave entertained wonnded men in his house, shall be exempted from the quartering of troops, as well as from a part of the contributions of war which may bc.imposed."

\section{Article 6.}

"Wounded or sick soldiers shall be entertained and taken care of, to whatever nation they may belong.

"Commanders-in-chief shall have the power to delirer immediately, to the outposts of the enemy, soldiers who have been wonnded in an engagement, when circumstances permit this to bo done, and with the consent of both parties.

"Those who are recognized, after they are henled, as incapable of serving, shall be sent back to their country.

"The others may also be sent back on condition of not again bearing arms during continuance of the war.

"Eracuations, together with the persons under whose directions they take place, shall be protected by an absolute neutrality."

\section{Article 7 .}

"A distinctive and uniform flag shall be adopted for hospitals, ambulances, and evacuations. It must, on every occasion, be accompanied by the national flag. An arm-badge (brassurd) shall also be allowed for indiriduals neutralized, but the delivery thereof shall be left to military anthority. 
"The flag and arm-badge shall bear a red cross on a white ground."

\section{Article 8.}

"The details of execution of the present Convention shall be regulated by the Commanders-in-chief of belligerent armies, according to the instructions of their respective Gorernments, and in conformity. with the general principles laid down in this Courention."

\section{Article 9.}

"The high contracting powers hare agreed to communicate the present Convention to those Governments which have not found it convenient to send plenipotentiaries to the International Gonference at Geneva, with an invitation to accede thereto; the protocol is for that purpose left open."

I will now consider these articles separately.

The first article naturally provided for the security of the lospitals in which the wounded might happen to be collected. Military; hospitals, both those in the field and those of a more permanent kind in rear, were to be recognized as nentral points, and to be safe from attack or disturbance. But as these hospitals were only to be respected for the sake of the rounded contained in them, it became necessary to stipulate that the presence in them of these sick or wounded was essential for ensuring a title to this consideration. IIospitals and their contents, when unoccupied by patients, would naturally fall under the ordinary rules of war, just as any other buildings or matériel. It became also evident, on discussion, that the stipulated immunity from attack of a hospital might, in certain situations and under certain circumstances, bo abused, and it rras necessary to provide against such an abuse. $\Lambda$ mortar battery might be so placed in rear of a hospital as to be incapable of attack so long: as the hospital itsclf had to bo respected; or tho hospital might be placed in a position of strategical importance, with a military force holding the position, under pretence of guarding the hospital. The restriction that the neutrality would cease if the hospital was held by a military force became therefore necessary. Of course a simple guard, for the maintenance of military order and discipline, was not intended to be included in this restriction.

Military hospitals, with cortain reservation, being thus recognized ns ueutral, it next became necessary to define the persomel who were to be included in the benefits of this neutrality, and to lay down any restrietions necessary for ensuring that the nentrality should only bo applied to the purposes for which it was admitted. In the first place, the neutrality of the hospital personnel was only agreed upon in the interest of the wounded, not for the individual benefit of the persons comprising the persomnel; and, in the secoud place, the interests of every army at large would require that steps should be taken to guard against persons moving among its ranks, and perhaps abusing the opportunity of 
observation thus afforded under cover of neutrality. With these ends in view, the second and third articles of the treaty were framed. In defining the personnel, all the classes of persons usually comprised in the official organization of military hospitals were included, not only the medical ofticers and their subordinates, but those also in whom the functions of general superintendence, administration of supplics, and transportation of wounded were vested; in short, all the official hospital establishments. To none of them, howerer, was accorded the neutrality; excepting so long as the sick and wounded needed their services. They might remain on duty with the wounded of the forces to which they were attached with impunity, eren after the conquering army had gained possession of the ground on which those wounded were-a great boon under circumstances where the conquered might happen to speak a different language from the conquerors, or when the latter liad limited means of surgical attendance at their disposal. When no wounded remained to require their services, the neutralized persons would be perinitted to rejoin the forces to which they belonged, and their neutrality would only cover them from the hospital up to their arrival at the advanced posts of these forces, to which they would be conducted under the charge of the army occupying the position from which they retired. These limitations obviated the risk of persons included in the second article abusing their neutrality for purposes of spying or idling.

The fourth article settles the terms on which the materiel of ambulances and hospitals is to be regarded under the treaty. By the first article, ambulances and military hospitals being only neutralized while containing sick or wounded, they and their contents would, by the laws of war, become the property of the conquering force when no sick or wounded remained in them. No reason for altering this was advanced so far as regards the fixed hospitals, but many reasons were found for mutually agreeing that this right of the conqueror should not be exercised so far as regarded the ambulances, or moring field hospitals. Take away the materiel from these-the stretchers and other articles of field transport, the means of dressing the wounded, the restoratives, the appliances for lessening the evils of transportation, and such things - and you deprive the soldiers who may be afterwards wounded, of their first means of safety, and add greatly to their suffeiings. Moreover, while the stores and furniture of stationary hospitals are 'often collected in abundance as reserves, and are costly, those of the ambulances are necessarily limited, and of little money value as prize of war to the captors. The materiel of the ambulances was therefore nentralized, while only the private property of the personnel employed in the fixed hospitals was protected by this articlc.

The best plan for securing another important means of succouring the wounded, especially after great battles, was a subject of much consideration. This was to secure the aid of the civil inhabitants of the towns and villages adjoining the site of the action, an object frequently found very difficult to attain. It was felt to be of the utmost importance to adopt measures for dissipating the alarm which so frequently causes these persons to flee from the neighbourhood, and 
for obtaining their services as early as possible after the conflict. At such a time the victorious army has generally to occupy itsclf not only with its own injured and dead, but also with numbers of the enemy, not to mention rarious other duties which derolve on it, and this is the very time when speedy remoral from the scene of conflict and immediate attention, is of vital importance to the wounded. Hence the fifth article was introduced, by which not only protection was promised to inhabitants assisting the wounded, but a dispensation from the quartering of troops and other advantages were agreed upon for those who received the wounded and attended upon them in their houses.

The sixth article binds the contracting parties to the treaty not only to give requisite care and treatment to all sick or wounded who may fall into their hands, but also enforces the important principle that the misfortunes of those who are disabled by the effects of their wounds are not to be aggravated by the many depressing influences which are entailed by banishment and loss of liberty :- they are not to be retained as prisoners of war. If circumstances admit, and mutual consent is given, the wounded may be given up at once, immediately after an action, to be cared for by their own army. Otherwise, if they are retained, and, after proper treatment, are found to be disabled for service, they are by the treaty to be sent back to their own country and friends. It is left optional, as regards the wounded who recorer completely from the effects of their injuries, for the contracting partics to determine whether they shall be sent back to their own country on condition of not serving again during the war, or whether this liberty shall not be granted. It was necessary to add a paragraph to this article to protect with neutrality not only the wounded or disabled soldiers while being convoyed to their destination, but those also who are engaged in the duty of directing the sick conroy.

To enable the neutralization of the ambulances, hospitals, ambulauce transport, and their personnel to be effectually carried out, it was necessary, as I have before mentioned, to fix upon a common sign by which they might be recognized by all parties joining in the treaty. $\Lambda$ flag was obviously the most convenient for the hospitals, both moving and fixed, and for sick convoys; but, for distinguishing the personnel, a brassard, or arm-badge, that could be readily worn orer a coat slecre, was fired upon as the most convenient. The design proposed was a red cross, alézée, upon a white ground, and being simple, and, moreorer, typical of the Christian principle of international charity embodied in the Convention, it was, unanimously adopted. There was also a propriety in adopting this design, for the colours being changed it was the national flag of the country in which the Congress was then sitting, and to which, - - a neutral country itself as it were in the midst of the Great Powers of Europe,-was due all the credit of the effort which was then being made to lessen the rigours of war by neutralizing its chicf sufferers. But in adopting this flag and common sign two things were necessary. Firstly, it was necessary to indicate not only the objects and persons having a right by treaty to 
be shiclded by jentrality, but also to show to what country they belonged; the national flag wis therefore required to accompany. the neutral flag whenever the hatter was used. Secondly, it was necessary to guard against any one asstuming the nse of the brassarl who had no official title to it; therefore it was left to the military authorities to issue the brasserds so that the right persons only should have them. To the Generals-in-chicf of the belligerent armies was also left by article $S$ the execution of the trenty in all other particulars under the instructions of their respective Governments; the object boing to guard against any such rigid fulfilment of its terms being cxacted as might on any occision interfere with the general military interests, which, of course, must always bo recognized ns overriding the interests of the wounded, and all other interests in time of war.

The ninth article provided for the treaty boing left open for tho subsequent admission of other Governments. A tenth article was included in the Convention, but this simply related to tho formal arrangements for its ratification.

I have thus passed rapidly in review the torms cmbodied in the several articles of the Genera Conrention of 186t, and brought to notice the points which formed the chief subjects of discussion at tho meetings of the Congress in reference to them. The treaty will materially lessen the misfortunes of those oflicers and soldiers who happen to be disabled by wounds or sicliness in time of war, for it establishes their neutrality and the neutralization of all that is essential to their preservation and restoration to their country and friends; and it does this without in my way interfering with the military interests of the belligerents. Its execution has been mutually agreed upon by a formal compact betreen the Gorcrmments of sixtecn countries and states, including all the great powers of Europe, with the exception of Austria and Russia, and, as the treaty is still open to them, it is to be hoped that, although they have not yet joined it, they will erentually do so, and that the principles of justice and humanity embodied in it, will becomo an established law among. all the civilised nations of the world. 'The anxious consideration that was given to the articles of the treaty not only by the delegates of such military nations as France and Prussia, but also by the higher military authorities in those countries (for constant communication was kept up with the central authorities during the sitting of the Congress) is calculated to remore any doubts as to the practicability of carrying: out the terms of the treaty. - But the practical nature of the compact is proved beyond donbt by the fact, that on certain occasions, as I have before remarked, to the honour of those concerned, the very provisions embolied in the treaty have been carried into practice by mutual special agrecment. An listorical account of these occasions was printed and laid before the Congress by the International Committeo at Geneva, and a notice of the principal among them may be found in the last edition of a little work entitled "La Charité Internationale sur les Champs de Bataille," which was published in Paris last year.

I have now to make a few remarks on the National Committees. 
I have before mentioned that the International Gonference of 1863 , in addition to paving the way for the Congress of 1864 , led to the establishment of National Committees in certain countries for assisting wounded soldiers in time of war, but I have not yet mentioned any particulars concerning these Committees. The general principles on which these Committees are formed were set forth by the Geneva Conference of 1863 in a series of ten resolutions. They may be summed up na follows. Each Central Committer is to organize itself, and to form sub-committees and sections, in the manner most suitable to the circumstances of the country in which it is placed, and to establish relations with the Government so that its offers of service may be acceptable when need of them shall arise. In time of peace, the Committee is to collect information on the best means of affording aid to the Government in case of war; to make itself acquainted with all improvements in the means of helping wounded soldiers; to employ itself in forming and training volunteers for service in hospitals approved by the authorities; to make a collection of the materials most necessary for sick and wounded; and, in short, to study all matters that may conduce to the great object of ameliorating their condition in time of war. Friendly relation are to be kept up between the National Committees of different nations, so that any improvements in field transport, or inventions likely to be serviceable to sick and wounded in campaigning, made in one country, may be made known in other countries, just as improvements in the implements of destruction are mutually observed, and generally without much reserve communicated, between nations on friendly terms with each other. In time of war, the Central Committees of the belligerent nations are to become the agents of the public at large for affording aid through the proper anthorities to the sick and wounded of the respective armies, and, if required to do so, but only if so required, are to place at the disposal of the military authoritics volunteer assistants foi service in hospitals, or even for carrying or otherwise helping the wounded in the field of action itself.

Committees based on these principles hare now been formed in nearly all the clice capitals of Europe. These Committees present the names of military and civil persons distinguished by their official rank or social standing, and are generally under the patronage of member's of royal families. In France, the Emperor has himself given marked encouragement to the undertaking, and the Central Committee in Paris has been constituted with the Minister of War as honorary president, and a General of Division as president. No Committce has as yet been formed in England, and I will presently mention some circumstances which lead me to think this a subject for regret.

Before stating them, however, I may mention that some of the National Committees formed since the Congress of 1863 have had the opportunity of practically exhibiting their usefulness in time of war. The campaign of Schleswig-Holstein in 1864 gave opportunities to the Central and Sectional Committees in Prussia, Austria, and Denmark of supplementing with advantage the official means of hospital assistance. The Central Committee at Berlin organized and furnished 
rolunteer assistance, both in materiel and personnel. An appeal was made for surgical aid, and it was answered by sixty-eight young ciril surgeons being sent to help in the hospitals nt the seat of war, with the consent of the military authorities. In Copenhagen and Vienna, the Central Committees equally collected funds and assistance of all kinds for the sick and wounded, and organized a systematic distribution of them.

Doubtless there will not bo less interest shewn as regards the troops of this country, should they become engaged in active hostilities of an extended nature, than has been exhibited in the more important wars of recent years; and there can be no one among us who is not familiar with the voluntecr plilanthropy of this nation, its liberality, and tho examples of personal devotion that were so.conspicuous during the Crimean campaign and the Indian mutiny. Indeed, in case of such a calamity occurring-I say calamity, for even when war is waged on the justest principles, for the protection of the weak, for the maintenance of national honour and independence, it is still acknowledged by all thoughtful persons to be one of the greatest calamities that can befall a nation-in such.a case it seems likely that public interest will be eren more s'rongly expressed than it was on the occasions to which I have referred, especially if the war in which our army be engaged should take place in Europe or in America. Somo of the circumstances which I named at the commencement of my remarks as being so favourable for the convocation of the Genova Congress of 1864; the strong hold and great influence which humanitarian doctrines have attained as one result of the spread of civilization; the great activity of thought among people at large; the rapid communication of intelligence to great centres almost irrespectire of distance, and its immediate circulation through whole communities; the facilities for personal morement and observation by lind and sea; all these are daily on the increase, and this increase will still further tend to ensure the maintenance of continued watchfulness, not only orer the army as a body, but also over the personal concerns, the health, and the welfare of all the individuals composing it. While the loss of life resulting from the direct effects of a battle must crer be regarded as one of the inevitable results of war, unnecessary loss of life from deficient means of transport for the wounded, deficient surgical aid, deficiency of needful supplies on the field of action, will be closely scrutinized. The wounded officers and soldiers will be watched from the place of fighting to the hospitals, and anxious attention wili be giren that in no way that can be aroided by care or expenditure of means, shall loss of life occur, or health suffer, while they are engaged in the active service of their country.

The best organization for meeting the urgent medical and surgical demands which would arise in time of war in the British army, has been most carefully studied. It would be out of place for me to refer here to the details of the plan on which the military medical arrangements have been approved by the Government of this country to be worked in time of war; suffice it for.me to say that I believe the system to bo as admirably contrived and as capable of expansion in 
case of need as that of the medical department of any army in the world. But even if the approred plan of assistance for the sick and wounded should be thoroughly carried into execution, and should bo practically applied, as regards the provision of materiel and personmel, in the same libenal spirit as was contemplated by those who designed it, this provision, liberal and well organized and well prepared as it would then be, would still. require to be supplemented by popular aid in case of a great battle or a prolonged campaign. No Government in the world could afford to mairtain a medical staff, or to provide the necessary means of meeting the wants of such a battle as that of Solferino, in the way that the wants of the wounded are now expected to be cared for. The percentage of wounded is stated to have been less at Solferino than it has been in any other great battle for many years past; but still the rast number of wounded which were thrown upon the care of the allies after that battle-about 20,000-not. to mention the sick requiring care at the same time: the great extent of ground over which they were scattered: the rapidity with which the troops had been concentrated, defeating all the efforts for bringing up at the same time many necessary surgical stores: these created demands that no Government establishment alone could have possibly supplied. The treaty of 1864 will facilitate to some extent the meeting of such emergencies in future, for a proportion of the surgeons and medical staff of the conquered can be left behind with their wounded without fear of being retained as prisoners of war; and the wounded themselves, as soon as they are fit to more, can be restored to their own countrymen for care and treatment, and the charge that will fall upon the conquerors will be thus proportionably lessened.

There are two directions in which, in such general engagements, deficiencies are liable to be experienced. One is in tho number of tho executive-the surgeons, and the hospital attendants upon whom so much depends, men trained for properly carrying the wounded, and for attending upon them nnder the directions of the surgeons;-the other is in the means of transport, and in hospital stores. One of the proposals, as I have beforo mentioned, at the International Conference of 1863, was that independent rolunteer aid in both these respects should be afforded on the field itself. I- have already said that this proposal cannot be held to bo generally practicable. T'o be ready to gire help at any moment, such a rolunteer establishment must move with the army; and the rationing of the men and of the transport animals composing the establishment and its movements by independent means in time of war, as proposed, could not be carried ont. But is this voluntecr assistance, therefore, inadmissible in every, way? 'This by no means follows as a matter of course, and here one of the useful qualities of the National Committecs might show itself. On the samo principle as in time of war, a portion of the home defence would be left to volunteer combatants, while militia regiments would be moved to talso the place of regular troops in colonial garrisons, and the regular troops be thus set freo for work in the field, so it scems feasible that under the direction of the National Committees, and with the concurrence of the Government, volunteer hospital corps could be utilised in time of war. N 2 
The men of the army hospital corps, under ordinary circumstances required for performing the duties of the home and of the intermediate hospitals which the necessities of war require to be established (and which will probably be greatly increased in numbers in future, from the now proved importance of distributing the sick and wounded over a wide area in small hospitals to prevent army epidemic diseases, instead of crowding them together in single towns or large buildings), this regular corps might in the same way be rendered available for duty in the field hospitals, their places in the former being taken by the volunteer assistants. But this plan, to answer, must be regularly organized on a definite system, in communication with the Government, and this would be the work of the Central National Committee. There would be no reason why volunteer hospital attendants, after sufficient experience, and with proper organization, should not be drafted to serve in the ficld to meet necessities that might exist there, on demand and under appropriate regulations. Energencies might arise in which, due regard being given to the just interests of the regular and permanent establishments, very valuable and material aid might be given by such means to the military anthorities and the Government, as well as benefit conferred on the sick and wounded of the army. So with material aid. During the Crimean campaign vast supplies were collected in England from hundreds of independent sources, but from want of system, a large proportion of the supplies, valuable as they were in themselves, were rendered useless from being inappropriate in kind, or from arriving when they were no longer required. In all recent wars, every Government has received aid from the nation towards supplying the wants of those injured in the nation's cause. At the opening of the Italian campaign in 1859, a depot was opened in Paris for the reception of old linen for the manufacture of clarpie, and in a few days some tons were presented, and other donations from the nation, for the sick and wounded of the French army rapidly followed. In Austria, from the number of sick and wounded sent out of Italy, shown by official returns to bo not less than 48,713 men, we are told " public sympathy and interest was largely aroused; hospitals were " opened in many remote places; the Empress formed one at Laxenberg; "others were opened at IIetzendorf, Trieste, near Vienna, and many " other places; ladies of the highest rank attended in these hospitals; " and patriotic societies everywhere arose who forwarded stores, food, " and money. The telegraph was of the most essential service in " rendering the distribution of the sick possible." I need do no more than allude to the wonderful work of the Sanitary Commission organised in the United States of America during the late civil war, for that has already been ably described by Mr. Fisher in a recent lecture in this theatre. I may remark, however, that I do not think any one can study the work of that vast association without coming to the conclusion that the beneficial influence it exerted as regi ids the armies of the United States was beyond calculation. With all the wonderful energy, the vast expenditure of treasure, the immense surgical resources, which the United States' Government brought to bear for the relief of the sick and wounded of their armies, and the able 
administration of the medical bureau at Wrashington, these means, without the aid afforded by the Sanitary Commission, would have been very far short of what was necessary for preserving the health of the troops in the degree in which it was preserved after that national association wus in full operation, and without this preservation of health most important adrantages must have been lost, and the war probably greatly prolonged. I have already alluded to what has been done by some of the National Committecs since their establishlment in 1864, and need not again refer to them. If a similar National Committee were established in England, one of its functions would be to organize the distribution of the national donations and aid on a proper footing. Should this country remain without the formation of such a committee, it will find itself at a disadvantage, as compared with neighbouring countries, in case of becoming engaged in a great war. Committees no doubt will be formed and subscriptions poured in as has happened hitherto, as soon as there is need of them; but, as heretofore, there will be absence of system and independence of action, and there will not be the advantage, at any rate at first, of Government support; while, in other countries, on war breaking out, the necessary preparations will have been long made and fully considered, everything will be systematised on preconcerted plans, so as to harmonise with the arrangements of the Gorernment and the action of the combatant and army medical authorities. These are some of the reasons which induce me to hope that this country may yet have its National Committee on the same footing as the National Committecs on the Continent.

In conclusion, I would observe that I hare purposely avoided any attempt at exciting feelings in favour of the Convention of 1864 , and of the formation of a National Committee in this country, by attempting to draw a picture of the sad collateral events which spring from war, or of the sufferings of those who in the course of duty fall wounded on the ficld of action, and become inmates of our military hospitals. Those who have been witnesses of fields of battle and the occurrences which follow in the ambulances and hospitals, need no description to induce them to attempt to mitigate, as far as practicable, the sufferings which are undergone in these situations; and to those who have not witnessed these scenes, any description from me would convey very inadequate ideas concerning them. Neither have I attempted to bring to notice the names of those who have alrendy stood prominently forward in trying to lessen these evils; they are recorded elsewherc. I havo attempted simply to carry out the plan I laid down at starting, viz., to give a plain narration of the circumstances which led to the International Congress of 1861, to lay before you a brief exposition of the articles of the treaty which resulted from it, and to give some account of the National Committees which have been formed in various countries for aiding in ameliorating the condition of sick and wounded soldiers in time of war, as well as to suggest some reasons for the formation of a National Committee with the same objects in view in this country. It appeared to me that $I$ should thus best fulfil the task I had undertaken at the request of the Council of this Institution. 
The Grimunas: We are extremely indebted to Professor Longmore for the rery interesting address which he has been so good as to give us on this most important stubject. He has traced the history of this morement and work, and he has shown us with what good judgment and good sense, and in how practical a manner, it has been carried on all through. IIe has observed that which 'I think must be patent to all of us, that when such efforts are made for the perfecting of thuse instruments of warfare by which luman life is destroyed, it is also natural and right that those who are influenced by feelings of liumanity, should employ their best exertions to endearour to preserve human life, and to lessen as far as possible the miseries and horrors of war. I believe no better means could be derised than those which hare been suggested, and which were described by Professor Longmore for the formation of these National Committees. I am myself acquainted with M. Dunant. I know how highly he is respected in his own country; I know low he was occupied before he deroted himself to this subject; and I know that his efforts have always been directed to the improvement of the condition of his fellow-countrymen, and to the promotion of every humane, religious, and civilising object. It appears to me that if this Committee can be carried out, in case we engage in it, it may have the effect of enabling us not only to mitigate the horrors of warin themselves, but really to form connections with those who may influence the various Governments of Europe to abstain from war, and to encourage ratlice the arts of peace. Wars may be necessary, as Professor Longmore has said, for the vindication of a nation's honour, and for the defence of one's own country; but the more public opinion can be brought to bear upon the Goreruments at whose instance wars aro undertaken, the nore benefit will accrue to nations at large. Professor Long: more has well said that the soldiers, who are the individual sufferers in war, are not those for whose interests wars are made. Professor Longmore very wisely abstained from harrowing our feelings with descriptions of what takes place in war; but there are a few words in one of these newspapers which hare been sent to me, which I will venture to read to you. It is in the Journal de Genèce, of February, 1864:-

"Rappelons aussi qu'í Flensbourg il y a peu de jours, faute d'une " organisation créée d'arance et de comités bien constitués, les " malheureux blessés n'ont pas été relevés, et que gisant ensanglantés " dans les rues de cette ville les roues des chariots de l'artillerio leur " ont passé sur le corps."

It really does convey an impression of the great want of medical aud surgical assistance in the time of war, that the poor creatures who had been fighting for their country were lying in the streets, and by a military necessity, artillery, being called to firo on the enemy, these poor creatures were absolutely destroyed by their own artillery passing over them. Now, if such a corps existed as Professor Longmore has suggested, a corps of voluntecr assistants in time of war, the wounded might hare been mored away, and most likely hey would have been tras sported from the place of danger, and 
received such assistance as could have been given them. There is ono sulject on which I feel extremely anxious myself in regard to what has been brought before us; that is, that if we take a part in this international work, our own Gorernment should not consider themselves in the least degree freed from the responsibility which in my opinion attaches to every Government, that of taking care of the sick and wounded in time of war. I believe it is true that no Gorernment can be prepared beforehand for all circumstances that are likely to take place, in case we' are engaged in a future war. It would, indeed, be a matter of great regret, and a great misfortune, if any Government should think itself liberated from its own first and most imperative duty, and I rejoico much to know that in the international exposition which is to take place in France in the course of the year 1867, a special department will be organized in this most humane and admirable cause, and that persons will be invited to exhibit any machines or instruments, or means of providing for the care of the sick and wounded in time of war, and that every facility will be given to afford information upon this most interesting and important subject. I see also that the Prussian National Committec has offered a rery handsome prize for suggestions upon this subject, and I hope some papers will be sent from this country. But the practical object which, I understand, Professor Longmore desires to bring before us, is rather that we in this country should establish a Committeo to co-operate with our own Govemment, and I suppose also with forcign Governments, for the promotion of this work. And if the lecture which Professor Longmore has given, should lead us to form such a Committee, I am sure we shall all rejoice in that which may relieve the distresses of war, and which may, under Divine Providence, have even the effect of preventing war.

General Sir TIlluas J. Codnisgtox, G.C.B.: There is one point upon which I desire to ask a question. Erery person must be gratified with the intelligence with which Professor Longmore has characterised his lecture. I think I heard lim mention that no country would go into war better prepared for the succour of the wounded than our own. It would be interesting to know what those preparations actually are for the care and removal of the wounded from the field to the field hospital, and from the field hospital to the more permanent hospital in the rear.

Professor Losgurone: In reply to the question, I would beg to say that the arrangements which have been made by our own Government, including those for the care of the wounded on the field of action itself, as well as others, for the transportation of the wounded from the field to the ambulances, or field hospitals, and, thence, to the hospitals in rear, are now defined in the authorized army medical regulations. I consider that these arrangements hare been made on as liberal a scale as those which exist in any European country.

General Codrisgtos: I only want to know what is the actual preparation? Are there men told off for the purpose? I want to come to the practical part of it.

Professor Losaxone: $\Lambda$ s regards the men, I can only practically 
speak of those told off for staff employ. $A$ s to those for regimental service, I only know that recommendations have been made, and orders have been issued to make provision for the proper care of what inay be expected to be the proportion of wounded of regiments in action by the previous instruction and preparation of certain soldiers in those regiments, set apart specially for this duty. The purpose was that these men, boing only trained for attending on the wounded, for liospital work, and not in rifle practice, should not be liable to be taken away for fighting purposes, leaving the wounded without proper relief; how far this is carlied out in practice I cannot say. As to the necessity for such a provision I don't think there can be two opinions. As regards the staff arrangements, there is now in this country an "Army IIospital Corps," which has only been formed or rather received its present constitution, since the Crimean war. That IIospital Corps now numbers about 1,000 men in its ranks. It is regularly organised. Every man belonging to the medical branch of the corps, nearly 500 in number, is systematically trained, or in course of being trained, in the duties of carrying and tendiug the wounded, both on the ficld itself, and in the hospital subscquently. There is eveiy reason to beliere that this corps will prove of essential service in time of war; though the number available for surgical duty being so limited, it will doubtless require expansion to meet the wants of a campaign. 